\title{
Expression of JUN, KROX, and CREB Transcription Factors in Goldfish and Rat Retinal Ganglion Cells Following Optic Nerve Lesion Is Related to Axonal Sprouting
}

\author{
Thomas Herdegen, ${ }^{1, *}$ Martin Bastmeyer, ${ }^{2}$ Mathias Bähr, ${ }^{3}$ Claudia Stuermer, ${ }^{2}$ \\ Rodrigo Bravo, ${ }^{4}$ and Manfred Zimmermann ${ }^{1}$ \\ 'II. Physiologisches Institut, Universität Heidelberg, Im Neuenheimer Feld 326, 6900 Heidelberg, \\ Germany, ${ }^{2}$ TFachbereich für Biologie, Universität Konstanz, 7750 Konstanz, Germany, ${ }^{3}$ Max-Planck- \\ Institut für Entwicklungsbiologie and Neurologische Universitätsklinik, Hoppe-Seyler Strasse 3, 7400 \\ Tübingen, Germany, and ${ }^{4}$ Department of Molecular Biology, Bristol-Myers Squibb Pharmaceutical \\ Research Institute, Princeton, NJ, 08543-4000
}

\section{SUMMARY}

Goldfish and rat optic nerves were cut and crushed, respectively, and the expression of the transcription factor proteins c-JUN, JUN B, JUN D, c-FOS, FOS B, KROX-24, and CREB was investigated in retinal ganglion cells (RGCs) by immunocy tochemistry. Immunoreactivities (IRs) were followed up to $\mathbf{3 5 0}$ days in the goldfish and up to 22 days in the rat. In RGCs of untreated goldfish and rats, all JUN, FOS, and KROX proteins were absent whereas CREB was constitutively expressed. After optic nerve cut in goldfish, a JUN-like immunoreactivity ( JUN-IR) appeared in a small number of RGCs of central retina after $24 \mathrm{~h}$, reached a maximum within 5 days, declined after 30 days, and was on a halfmaximal level after 50 days. Between 100 and 200 days, JUN-IR was only visible in a few RGCs and was completely absent after 350 days. Specific antibodies against c-JUN, JUN B, and JUN D gave no distinct immunoreactive signal. Thus, we could not determine which member of the JUN family contributed to the JUN-IR. The expression of CREB declined after 5 days. The number of CREB-labeled RGCs was reduced (not signifi-

\section{INTRODUCTIION}

Lesions of nerve fibers evoke complex changes in the protein synthesis of damaged neurons (re-

Received October 16, 1992; accepted December 9, 1992

* To whom correspondence may be addressed. cant) and the intensity of labeling faded out. After 50 days, CREB-IR had returned to basal level. c-FOS, FOS $B$, and KROX-24 could not be detected in goldfish RGCs following optic nerve cut. After optic nerve crush in the rat, c-JUN, JUN D, and KROX-24 appeared in a substantial number of RGCs after $24 \mathrm{~h}$, had a maximal expression after 5 days, and strongly declined after 8 days. c-JUN and KROX-24 were completely absent after 22 days whereas JUN D was still present in a few rat RGCs. The number of CREB-labeled RGCs decreased after 5 days and had declined by $\mathbf{5 0} \%$ after $\mathbf{2 2}$ days. Expression of JUN B, c-FOS, FOS B could not be detected in rat RGCs after optic nerve crush. Our data demonstrate that the decrease of CREB and the increase of JUN and KROX-24 transcription factors precedes and parallels both the alteration of de novo protein synthesis and the axonal sprouting, which are long lasting in goldfish and transient in rat. () $1993 \mathrm{John}$ Wiley \& Sons, Inc.

Keywords: growth-associated proteins, immediate-early genes, regeneration, transcription. 
rons following lesions of peripheral nerve fibers (Herdegen, Kummer, Fiallos, Leah, and Bravo, 199lb; Leah, Herdegen, Kovary, and Bravo, 199I; Jenkins and Hunt, 1991; Herdegen, Fiallos, Schmid, Bravo, and Zimmerman, 1992b). In addition, a decrease of expression of CREB transcription factor (also termed CREBP-1; Gonzalez, Yamamoto, Fischer, Karr, Menzel, Biggs, Vale, and Montminy, 1989) was seen in axotomized motoneurons (Herdegen et al., 1992b). The CREB protein holds a superior position in the hierarchy of transcriptional operations by controlling the expression of genes encoding for inducible transcription factors such as $c$-jun and $c$-fos (Macgregor, Abate, and Curran, 1990; Lamph, Dwarki, Ofir, Montminy, and Verma, 1991; Sheng, McFadden, and Greenberg, 1991).

In the present study, we investigated the expression of c-JUN, JUN B, JUN D, c-FOS, FOS B, and KROX-24 (also termed NGFI-A, Egr-1, Zif/268) and CREB proteins in retinal ganglion cells (RGCs) of goldfish and rats following optic nerve lesion. RGCs of rats and goldfish differ in their potency for regeneration. In the goldfish, transection of the optic nerve (ON) is followed by extensive sprouting and functional reestablishment of the neuron-target axis (Meyer, 1980; Schmidt, Edwards, and Stuermer, 1983; Stuermer and Easter, 1984; Stuermer, Bastmeyer, Bähr, Strobel, and Paschke, 1992). In contrast, axotomized rat RGCs undergo degeneration and neuronal cell death after a short sprouting response (Misantone, Gershbaum, and Murray, 1984; Barron, Dentinger, Krohel, Easton, and Mankes, 1986; Villegas-Perez, Vidal-Sanz, Bray, and Aguayo, 1988; Bähr, 1991). The present study was designed to provide new insights into the transcriptional mechanisms that might underly the different regenerative responses of rat and goldfish RGCs following optic nerve lesions.

\section{METHODS}

\section{ON Lesions}

The ONs of adult goldfish ( $8-10 \mathrm{~cm}$ long) were cut on both sides under MS-222 anesthesia. After survival times of 24,36 , and $48 \mathrm{~h}, 5,10,15,30,50,100,200$, and 350 days ( each $n=2$ ), goldfish were reanesthetized and eyes were dissected. In two goldfish, the $\mathrm{ON}$ was only unilaterally crushed and both the crushed and intact eyes were dissected after 5 days. In female Lewis rats (200-330 g), the left $\mathrm{ON}$ was intraorbitally crushed under deep anesthesia (chloral hydrate, $0.42 \mathrm{mg} / \mathrm{kg}$, IP). After survival times of 24 and $48 \mathrm{~h}, 5,8,14$, and 22 days (each $n=2$ ), rats were reanesthetized and transcardially perfused by $4 \%$ paraformaldehyde and eyes were removed. The retinae of rats and goldfish were postfixed overnight in the same fixative and cryoprotected in $30 \%$ sucrose for further $48 \mathrm{~h}$.

\section{Immunocytochemistry}

Twenty-micrometer cryostat sections of rat and goldfish retinae were sagitally cut and processed for immunocytochemistry and immunofluorescence on gelatine-coated slides. Sections were preincubated with goat serum for 1 $\mathrm{h}$, incubated for $36 \mathrm{~h}$ with polyclonal anti-c-JUN ( $607 / 3$ 1:1000 and 636/3 I:8000), anti-JUN B (1:2000), antiJUN D (1:5000), anti-c-FOS (1:5000), anti-FOS B (1:1000), anti-KROX-24 (1:5000), and anti-CREB $(1: 2000)$ rabbit antisera and visualized by the avidinbiotin complex method (Vector Lab., Burlingame, CA) . The specificity of these antibodies has been determined in vitro (Boshart, Weih, Nichols, Schütz, 1991; Kovary and Bravo, 1991) and in vivo (Herdegen, Kovary, Leah, and Bravo, 199la; Herdegen et al., 1992b). The antibody against CREB was a generous gift of Dr. W. Schmid (German Cancer Research Center, Heidelberg).

In some experiments, goldfish and rat retinae were double labeled with the polyclonal anti-c-JUN antiserum (636/3) and a monoclonal antibody against neurofilament (SMI-31, Sternberger and Meyer, Inc.) to identify RGCs. Sections were first treated with methanol $\left(-20^{\circ} \mathrm{C}, 5 \mathrm{~min}\right)$, washed in phosphate-buffered saline, and incubated with anti-c-JUN (1:1000) and SMI-31 ( $1: 1000)$ simultaneously for $2 \mathrm{~h}$. Primary antibodies were visualized by FTC-coupled goat antirabbit and rhodamine-coupled goat antimouse antibodies (1:200, Dianova). Some sections were counterstained using DAPI, a general marker of DNA.

\section{Statistics}

In each animal, immunoreactive RGCs were counted in three sagittal sections of the retina that contained the $\mathrm{ON}$. The numbers were averaged and means $( \pm S D)$ were calculated for each protein and each time point. Significances were calculated by Student's $t$-test $(p \leq 0.05)$.

\section{RESULTS}

\section{Identification of Retinal Ganglion Cells in Goldfish and Rats}

In the retina layer of goldfish and rats, the nuclei labeled by JUN, KROX-24, and CREB could be distinctly identified as RGCs. Staining of nuclei by DAPI showed that the distribution of labeled RGCs was congruent with the distribution of largediameter nuclei labeled by DAPI [Figs. 1(A-D)] The morphologically characteristic distribution of 

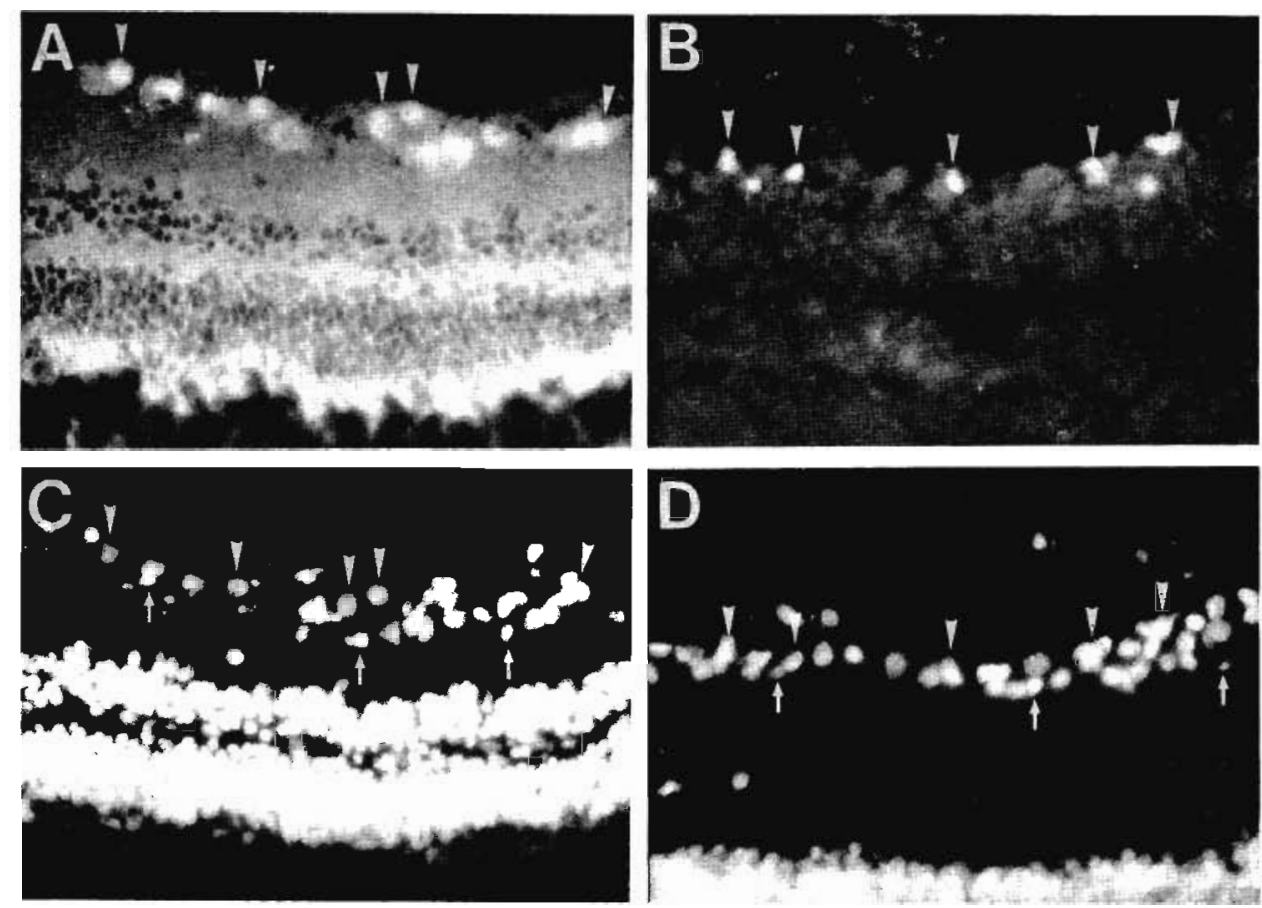

Figure 1 Double-labeling of c-JUN-IR (A, B) and DAPI (C, D) in retinae of goldfish $(A, C)$ and rats $(B, D) 3$ days following optic nerve lesions. C-JUN-IR is restricted to the RGC layer. Comparison with DAPI demonstrates that $\mathrm{c}-J U N-I R$ is confined to large-diameter nuclei (arrowheads) whereas c-JUN-IR is absent in small-diameter nuclei labeled by DAPI (arrows). In rat $\mathrm{RGCs}(\mathrm{B}, \mathrm{D})$; not all large-diameter cells are labeled by c-JUN because at 3 days c-JUN-IR has not reached its maximal-expression. Magnification, $600 \times$.

labeled nuclei within the RGC layer showed a tangential orientation typical for RGCs. Double labeling by c-JUN and neurofilament that selectively marks RGCs in the retina ganglion cell layer gave a perfect colocalization for both proteins (not shown).

\section{Expression in Goldfish Retinae}

JUN. The JUN-like immunoreactivity (JUN-IR) in goldfish RGCs was evoked by an anti-c-JUN antibody (code 636/3) that recognized in vitro all three JUN proteins (c-JUN, JUN B, and JUN D) (Kovary and Bravo, 1991). Specific antibodies against c-JUN, JUN B, and JUN D gave no distinct nuclear IR in goldfish RGCs. In the retinae of untreated goldfish, no JUN immunoreactivity could be detected. Twenty-four hours following ON crush, JUN-IR appeared in RGC nuclei of the central region of retina [Figs. 2(A,B), 3]. After 48 $\mathrm{h}, \mathrm{JUN}-\mathrm{IR}$ became also visible in the peripheral RGCs and reached a maximum after 5 days for both the number of labeled RGC nuclei [ $301 \pm 48$ $\mathrm{c} / \mathrm{s}$ (cells per section)] and the intensity of labeling [Figs. 2(C,D) 3]. This maximal expression persisted up to 20 days. After 30 days, the number of JUN-labeled RGCs started to decline [Fig. 2(E)] and after 50 days the labeled RGCs had decreased by around 50\% [Fig. 2(F)]. Between 100 and 200 days, only a few labeled RGCs could be found [Fig. $2(\mathrm{G})]$. At the end of the observation period, 350 days, JUN-IR was completely absent [Figs. 2(H) and 3]. Double labeling with DAPI and c-JUN demonstrated that all large-diameter nuclei were labeled by JUN-IR following ON cut [Figs. $1(\mathrm{~A}, \mathrm{C})]$.

c-FOS, FOS B, KROX-24. We could not detect a nuclear labeling for c-FOS, FOS B, and KROX-24 in untreated goldfish and following ON lesion.

CREB. The CREB protein was constitutively expressed in RGCs, including those of peripheral ret- 

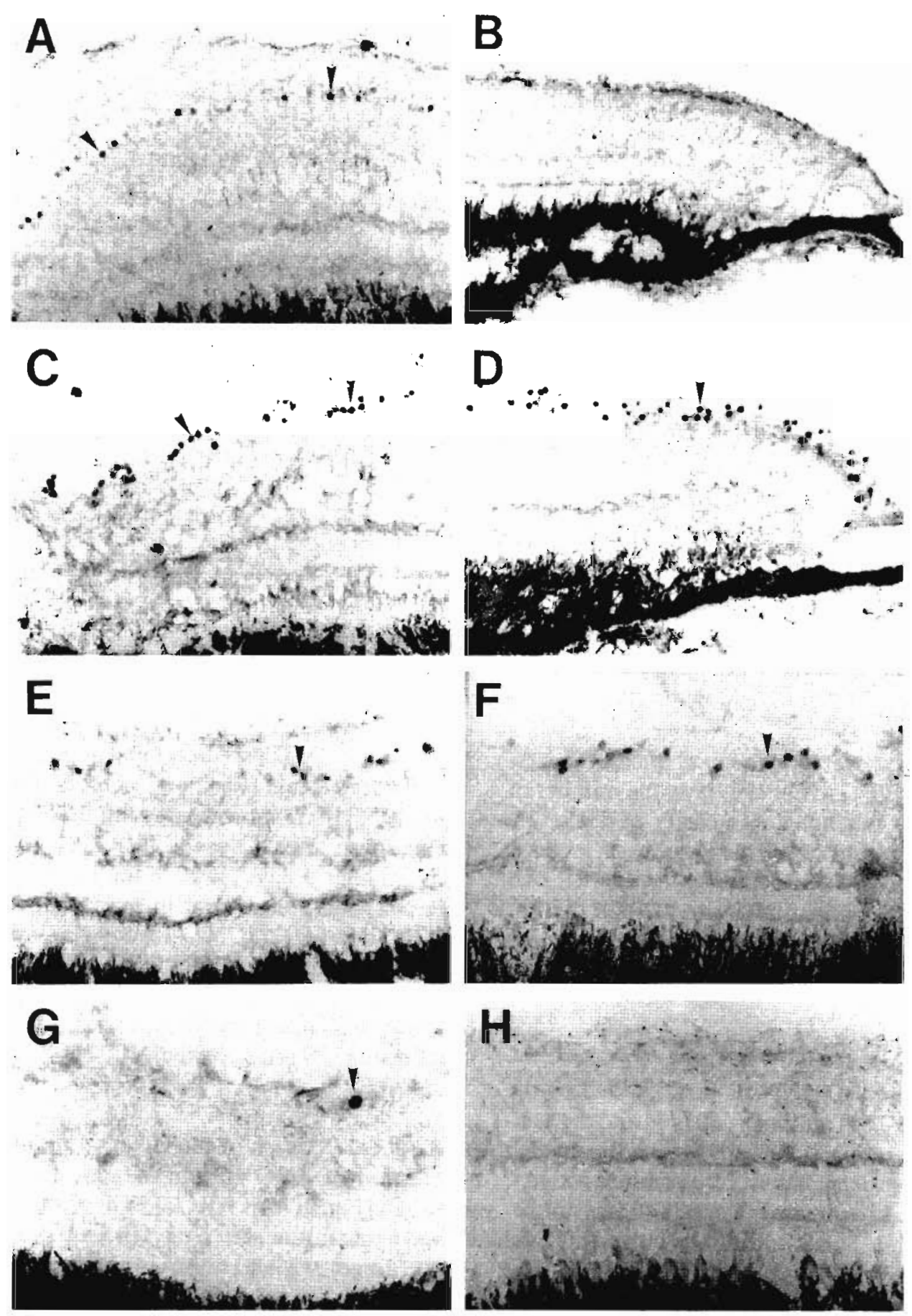

Figure 2 JUN-IR in goldfish RGCs following optic nerve cut. After $36 \mathrm{~h}$, expression in central (A) and absence in peripheral retina (B); after 5 days, maximal expression in central (C) and peripheral retina (D); decline of JUN-IR after 35 days (E), 50 days (F), 100 days (G), and 350 days $(\mathrm{H})$. Arrowheads mark labeled nuclei in RGC layer. Magnification, 500×.

ina $(329 \pm 61 \mathrm{c} / \mathrm{s})$, and cells of the inner nuclear layer (INL) [Fig. 3, 4(A,B)]. CREB-labeled RGCs were homogenously distributed within the RGC layer. Changes in CREB-IR were visible between
$48 \mathrm{~h}$ and 30 days. During this period, the intensity of labeling was diminished and the number of labeled RGCs was nonsignificantly reduced (234 $\pm 49 \mathrm{c} / \mathrm{s})[$ [Fig. $4(\mathrm{C}-\mathrm{F})]$. After 50 days, CREB-IR 


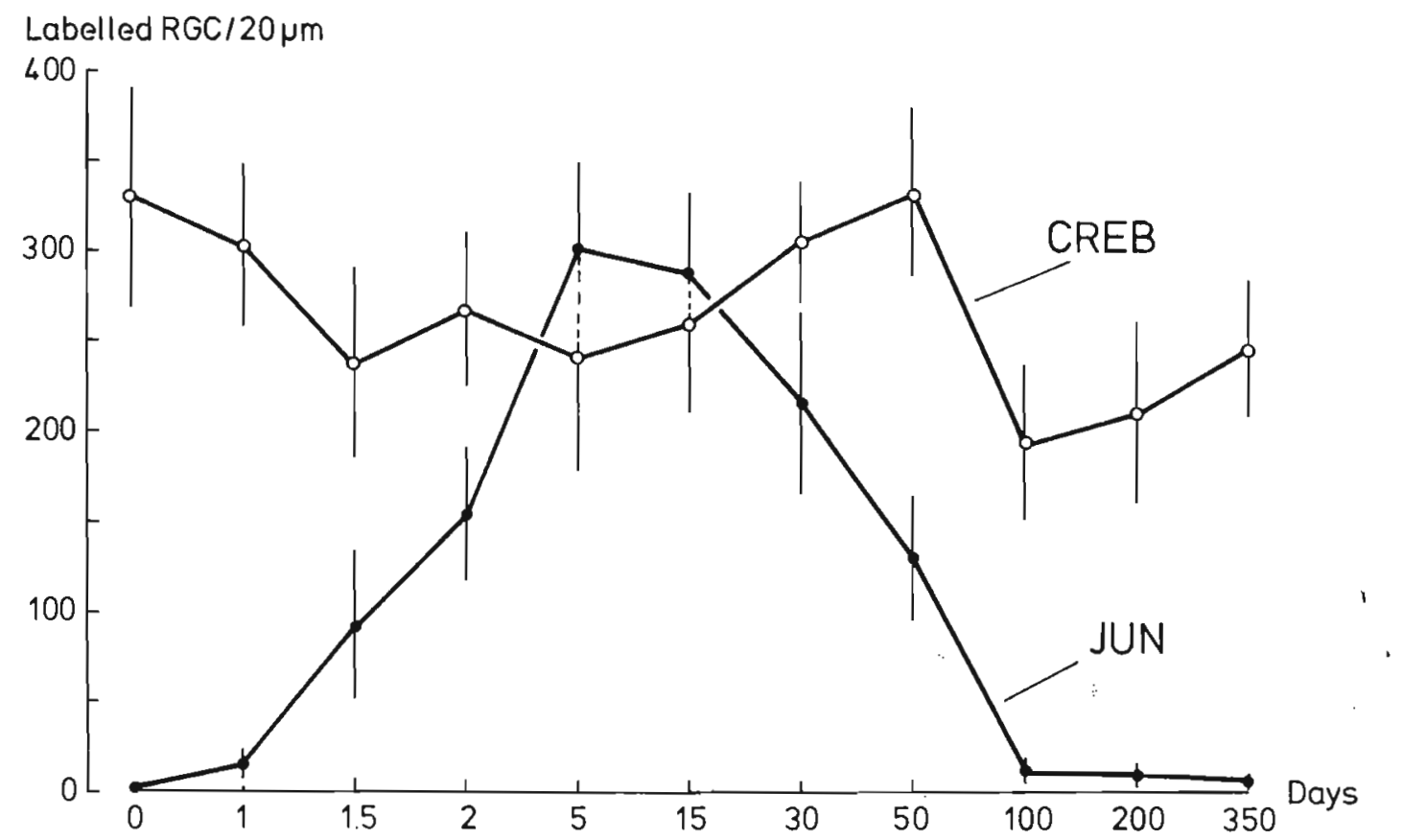

Figure 3 Time course of RGCs labeled by JUN ( $\bullet$ ) and CREB (O) in the goldfish following optic nerve cut. The numbers give mean \pm SD from three sections, each of two goldfish.

of RGCs had recovered to the level of basal expression [Figs. 4(E,F)]. After 100 days, the number of labeled RGCs but not the intensity of CREB-IR decreased again and recovered to subbasal levels at 350 days [Figs. $3,4(\mathrm{G}, \mathrm{H})$ ].

Immunoreactivities of JUN and CREB did not change in RGCs of the contralateral untreated eye.

\section{Expression in the Rat Retina}

$c$-JUN. In the rat, c-JUN-IR was detected by the specific anti-c-JUN antibody (607/3) and the nonspecific anti-c-JUN antibody $(636 / 3)$, which evoked a congruent pattern of immunoreactivity. In the retinae of untreated rats, c-JUN was not detectable. Within $24 \mathrm{~h}$ following ON cut, c-JUN was expressed in RGCs but expression of c-JUN was not visible in the peripheral part of the retina [Figs. 5(A,B) and 6(A)]. After 5 days, c-JUN had a maximum for intensity of labeling and number of labeled RGCs in the entire retina $(254 \pm 38 \mathrm{c} / \mathrm{s})$ [Fig. 5(C)]. After 8 days, the number of RGCs labeled by c-JUN was significantly reduced and was completely absent in rat RGCs after 22 days [Figs. 5(D) and 6(A)]. Double labeling with DAPI showed that c-JUN-immunoreactive nuclei were large-diameter nuclei, but not all large-diameter nuclei were labeled by c-JUN [Figs. 1(B,D)].
JUN D. JUN D was detectable only in few RGCs of untreated rats [Figs. 6(A) and 8(A)]. Expression of JUN D increased within $24 \mathrm{~h}$, reached its maximum after 5 days $(219 \pm 34 \mathrm{c} / \mathrm{s})$, and declined after 8 days [Figs. $8(\mathrm{~B}, \mathrm{C})$ ]. After 22 days, JUN D was still present in numerous cells [Figs. 6(B) and 8(D)]. JUN D-IR was also visible in the INL. The pattern of JUN D-IR differed from that of c-JUN-IR: JUN D-IR, but not c-JUN, was detected in RGCs of untreated rats and after 22 days following ON crush; further, JUN D-IR was visible in INL.

$K R O X-24$. Crush of the $\mathrm{ON}$ also induced the expression of KROX-24 in a small number of rat RGCs [Fig. 9(A)]. KROX-24 appeared after $48 \mathrm{~h}$, had a maximum after 5 days $(15 \pm 9 \mathrm{c} / \mathrm{s})$, and was no longer visible after. 14 days [Figs. 6(B), $9(\mathrm{~A}, \mathrm{~B})]$.

JUN B, C-FOS, and FOS B. We could not detect expression of JUN B, c-FOS, and FOS B in RGCs of untreated rats and following ON cut.

CREB. CREB was constitutively expressed in RGCs of untreated rats $(281 \pm 52 \mathrm{c} / \mathrm{s})$ [Figs. 6(A), $7(\mathrm{~A})$ ]. CREB-IR declined after 2 days. After 8 and 22 days, the number of labeled RGCs decreased by 44 and 56\%, respectively [Figs. 7(B-D)]. 

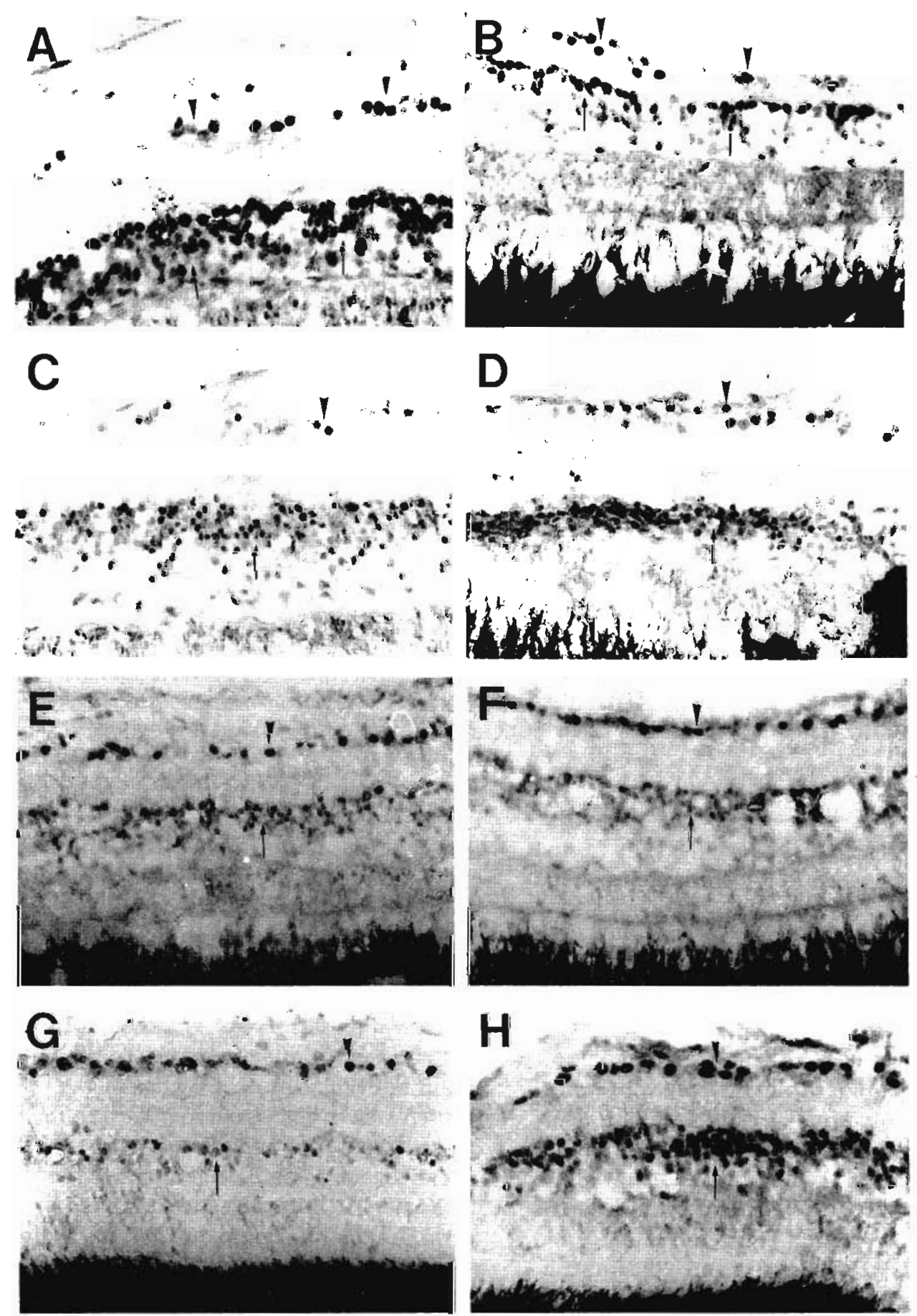

Figure 4 CREB-IR in the goldfish. Constitutive expression of CREB in central (A) and peripheral (B) retinae of untreated goldfish. Five days following optic nerve cut, CREB-IR is decreased in centraI (C) and peripheral (D) retinae; after 50 days, CREB-IR had returned to basal levels in central (E) and peripheral ( $F$ ) retinae; CREB-IR after 100 days $(G)$ and 350 days $(H)$ in central retinae. Arrowheads mark labeled nuclei in RGC layer; arrows mark the INL. Magnification, 500X. 

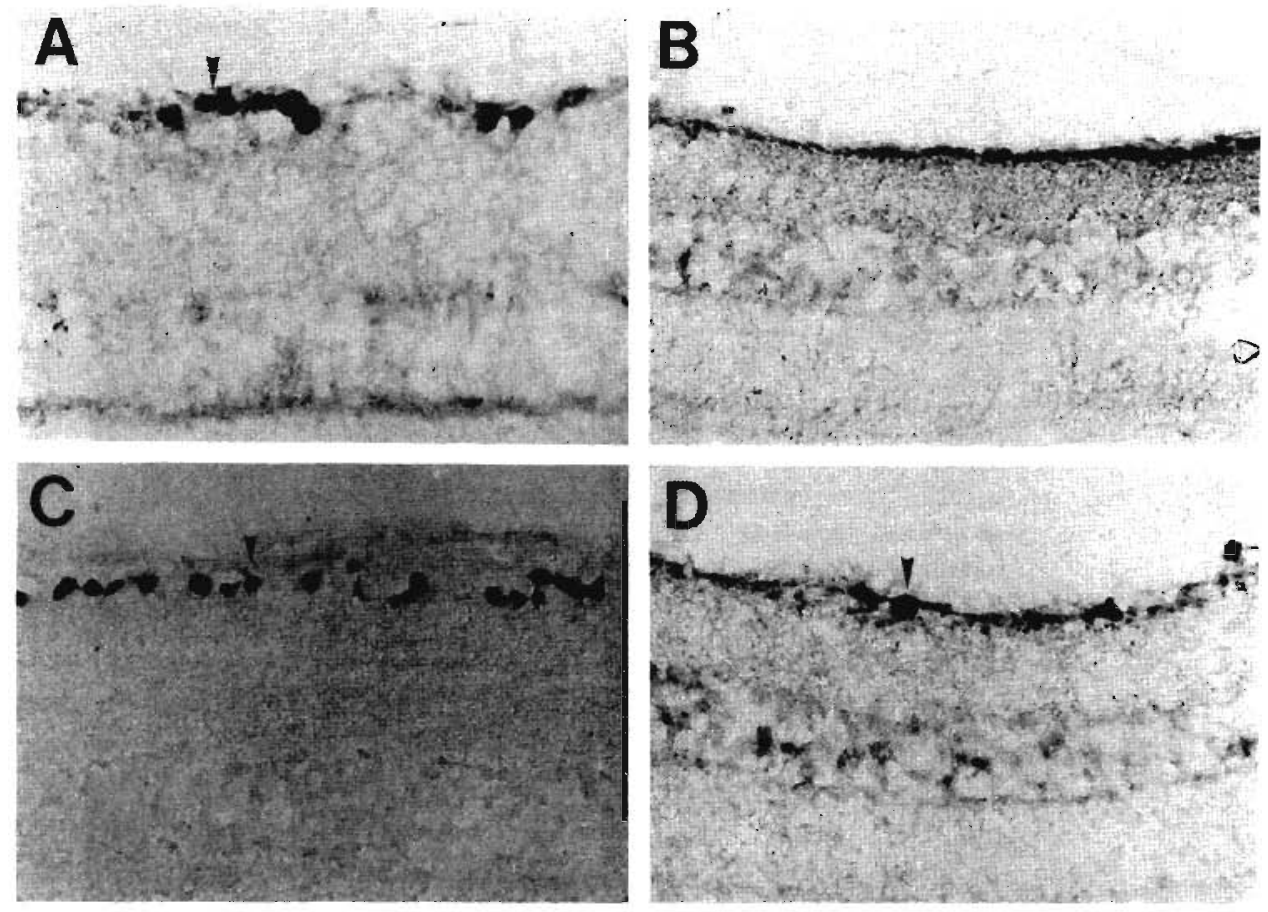

Figure 5 c-JUN-IR in rat RGCs following optic nerve crush. After $24 \mathrm{~h}$, c-JUN is visible in central (A) but not in peripheral (B) retinae. Maximal c-JUN-IR after 5 days (C). Decreased c-JUN-IR after 8 days (D). Arrowheads mark labeled nuclei in RGC layer. Magnification, $600 \times$.

The immunoreactivities of c-JUN, JUN D, and CREB did not change in RGCs of the contralateral untreated eye.

\section{DISCUSSION}

In two animal species with different potentials for axon growth, the goldfish and rat, the expression of transcription factor proteins c-JUN, JUN B, JUN D, c-FOS, FOS B, KROX-24, and CREB was investigated in RGCs following ON lesions. We have reported a long-lasting JUN-IR in goldfish RGCs and a transient expression of c-JUN, JUN D, and KROX-24 in rat RGCs. In contrast to the immediate-early gene-encoded proteins, CREB was basally expressed and decreased following $\mathrm{ON}$ lesions. JUN B, c-FOS, and FOS B were not detectable. The labeled cells could be identified as RGCs.

JUN, FOS, and KROX-24 proteins belong to the group of IEG-encoded nuclear transcription factors (reviewed by Bravo, 1991). These proteins are selectively and/or commonly activated by transmembrane stimuli and are expressed in an individual temporospatial order (Almendral, Sommer, MacDonald-Bravo, Burckhard, Perera, and
Bravo, 1988; Bartel, Sheng, Lau, and Greenberg, 1989; Sonnenberg, Macgregor-Leon, Curran, and Morgan, 1989a; Gass, Herdegen, Kiessling, and Bravo, 1992; Herdegen et al., 1991a; Herdegen, Leah, Manisali, Bravo, and Zimmerman, 1991c; Kovary and Bravo, 1991). IEG-encoded nuclear transcription factors are supposed to translate the extracellular stimulation into an adaptive alteration of cellular protein synthesis. JUN and FOS proteins have been shown in vitro to be involved in the transcription control of the NGF gene, proenkephalin, and prodynophin (Sonnenberg, Rauscher III, Morgan, and Curran, 1989b; Hengerer, Lindholm, Heumann, Rüther, Wagner, and Thoenen, 1990; Naranjo, Mellström, Achaval, and Sassone-Corsi, 1991). CREB represents a constitutively expressed transcription factor that is activated by phosphorylation (Gonzalez et al., 1989) and controls the transcription of both IEGs and effector genes (Goodman, 1990; Lamph et al., 1990; Sheng et al., 1990).

\section{Transcription Factors in Goldfish RGCs}

Antibodies that in vitro specifically react with individual JUN proteins (c-JUN, JUN B, or JUN D) 

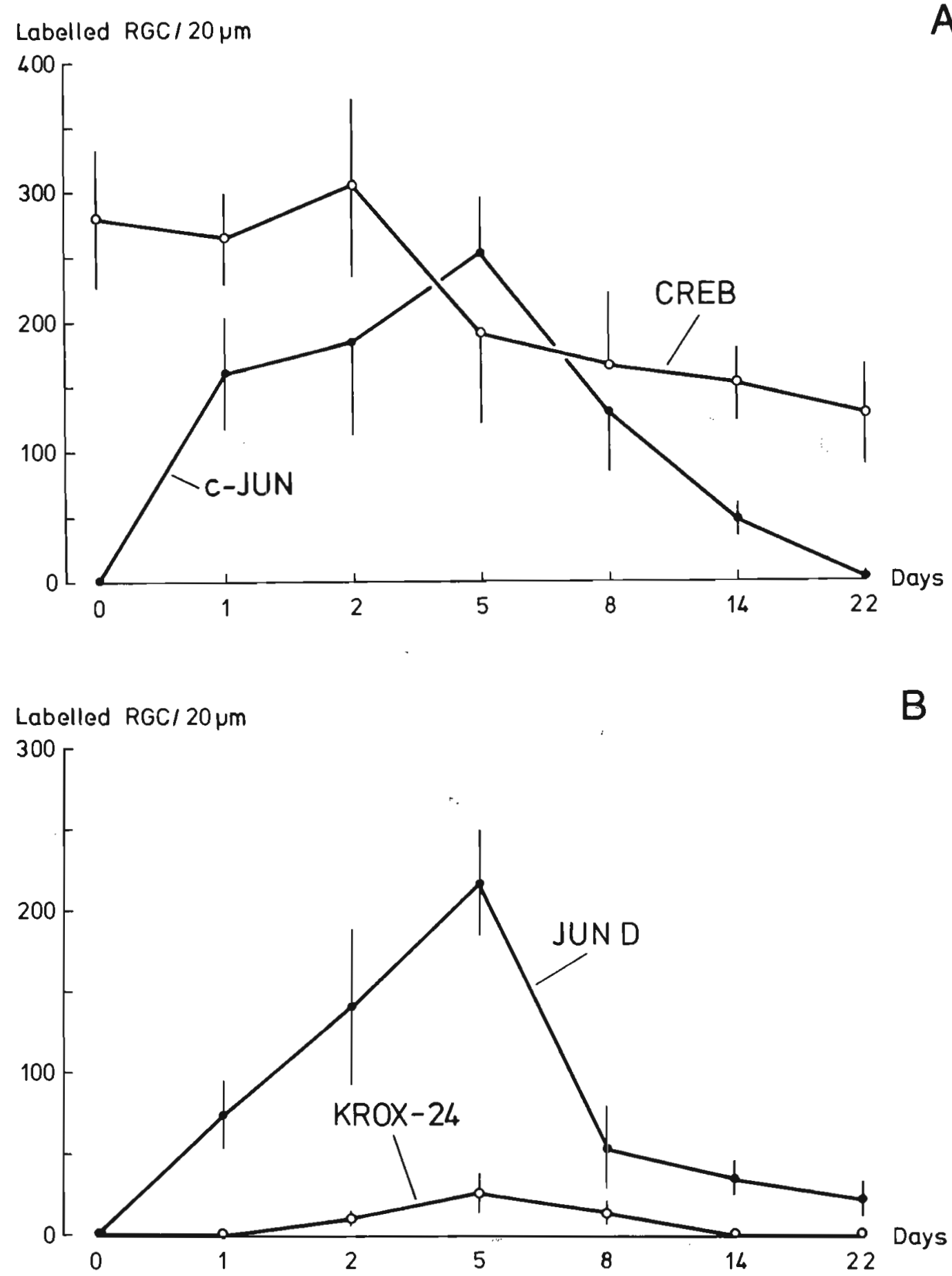

Figure 6 Time course of rat RGCs labeled by c-JUN ( ) and CREB (O) (A) and by JUN D (-) and KROX-24 (O) (B) following optic nerve crush. The numbers gives mean \pm SD from three sections, each of two rats.

gave no immunoreactive signal in goldfish retinae. JUN-IR was evoked by an antibody (code 636/3) that in vitro cross-reacts with all three JUN proteins (Kovary and Bravo, 1991). In many investigations of rat nervous tissue, we have found that this antibody (code 636/3) and a specific c-JUN antibody (code 607/3) evoked a similar pattern of immunoreactivity (Herdegen et al., 1991c; Gass et al., 1992). Because of its relatively low affinity, the specific anti-c-JUN antibody may not react with 


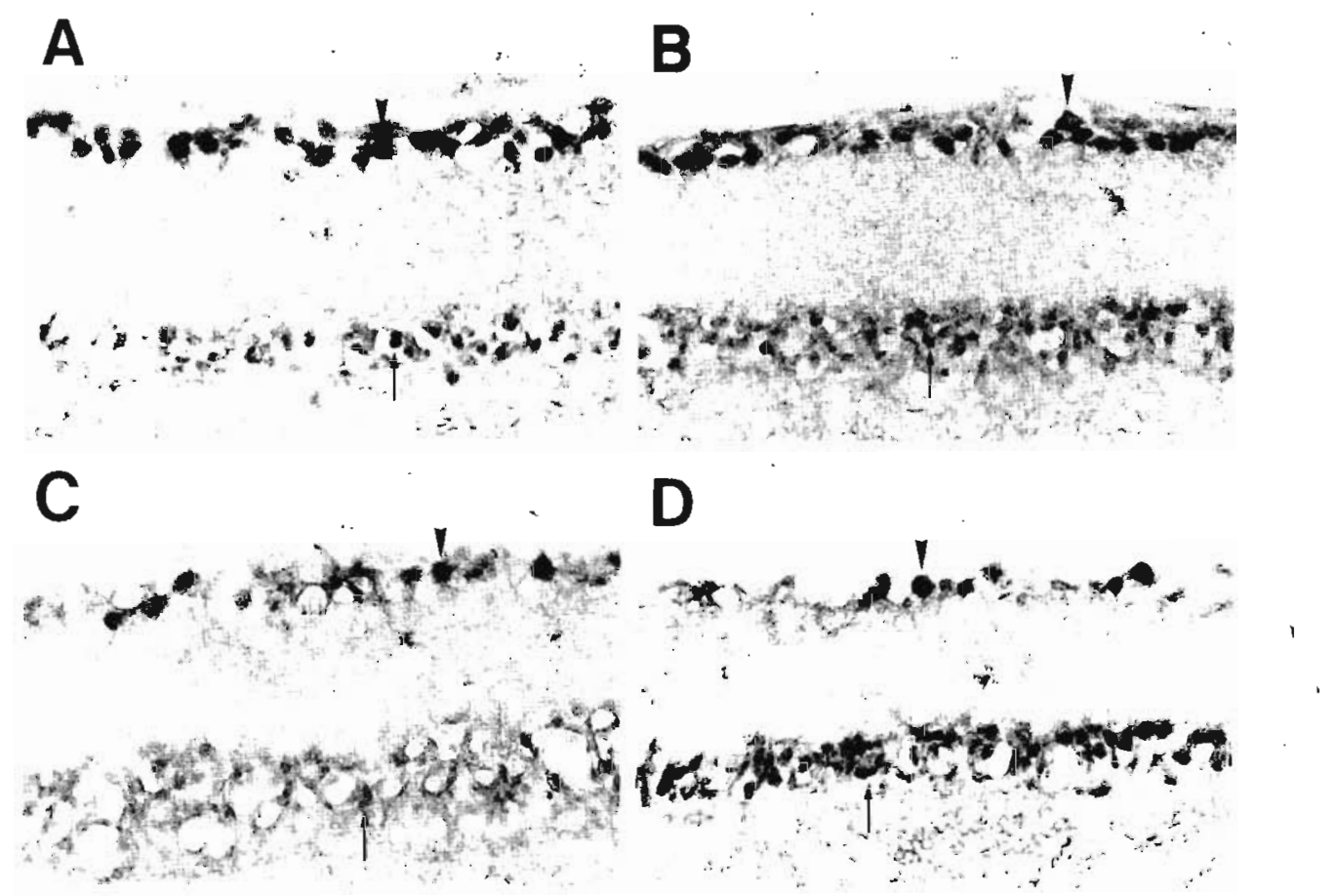

Figure 7 CREB-IR in the rat RGC layer. In untreated rats (A), after 5 days (B), 8 days (C), and 22 days (D) following optic nerve crush. Arrowheads mark labeled nuclei in RGC layer; arrows mark labeled nuclei in INL. Magnification, $600 \times$.

the goldfish c-JUN antigen. No data are available about the structure of JUN proteins in fish and which may not be completely homologous to mammalian JUN proteins.

In untreated goldfish, JUN-IR was absent in RGCs of central and, interestingly, peripheral retinae. Peripheral RGCs are ontogenetically young and form new optic nerve axons in the ongoing growing retina (Johns and Easter, 1977). Twentyfour hours following ON cut, JUN-IR appeared in RGCs of central but not peripheral retinae. This could be due to the shorter ON stump of central RGCs compared to that of peripheral RGCs with subsequent shorter latency of axonal signal transfer after ON lesion. On the other hand, the short ON stump of central RGCs may provide only a restricted amount of trophic factors compared to the longer ON stump of peripheral RGCs, which could result in a faster and more intense cell body response with an enhanced expression of JUN. Similarly, ventral rhizotomy of the rat sciatic nerve evokes a much more intense c-JUN expression in axotomized motoneurons compared to peripheral sciatic nerve transection (Leah et al., 1991). The early appearance of transcription factors such as JUN proteins could contribute to the more rapid axonal regeneration of the ontogenetically older RGCs of central retina compared to the young RGCs of peripheral retina (Lowenger and Levine, 1988). In fish, peripheral RGCs are sensitive to axotomy, similar to young mammalian neurons (Lieberman, 1974; Allcut, Berry, and Sievers, 1984), e.g., ON lesion causes a cessation of mitotic activity at the retinal margin for several days in the goldfish (Keefe, 1973) and axotomized RGCs of juvenile zebrafish do not regenerate their axons (Kuschel and Stuermer, 1988). These findings may contribute to and are reflected by the delayed JUN expression in peripheral RGCs. Unlesioned peripheral RGCs could become coupled to axotomized RGCs, e.g., by activated glial cells ( Bähr and Schlosshauer, 1989), with subsequent expression of JUN.

The onset of JUN-IR preceded and paralleled the observed changes of RNA and protein synthesis due to axotomy. Increase of RNA synthesis, incorporation of $\left[{ }^{3} \mathrm{H}\right]$ uridine, and enlargement of nucleolar mass have been discriminated at the third day (Murray, 1973; Murray and Grafstein, 1969; Dokas, Kohsaka, Burrell, and Agranoff, 1981; McQuarrie and Grafstein, 1982b). Also, the significant increase in amino acid incorporation 

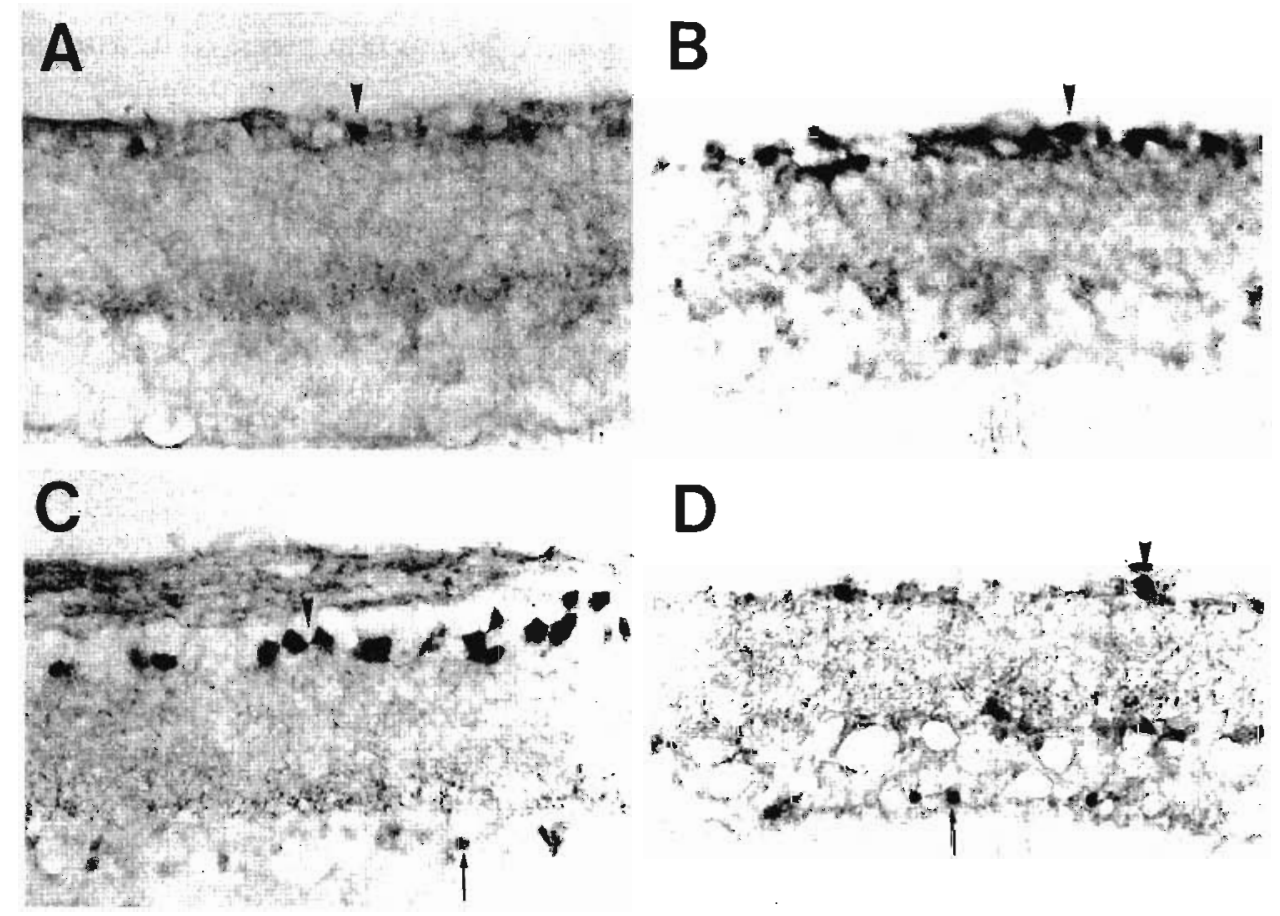

Figure 8 JUN D-IR in the rat RGC layer. In untreated rats (A), increase after $48 \mathrm{~h}$ (B), maximal expression after 5 days $(C)$, and decrease after 22 days (D) following optic nerve crush. Arrowheads mark labeled nuclei in RGC layer; arrows mark labeled nuclei in INL. Magnification, $600 \times$.

into proteins and increase in protein synthesis do not start before 3-4 days (Murray and Grafstein, 1969; Whitnall and Grafstein, 1983; Barron, McGuiness, Misantone, Zanakis, Grafstein, and Murray, 1985). Within 5 days following ON lesion, JUN-IR has reached its maximum with regard to both the number of labeled RGCs and the intensity of labeling in individual RGCs. The peak of JUN-IR also precedes and parallels the peak of protein synthesis, which is between 14 and 20 days. JUN-IR declines after 30 days at parallel to the decrease of protein synthesis (Murray and Grafstein, 1969; McQuarrie and Grafstein, 1982a; Grafstein et al., 1987; Larrivee and Grafstein, 1989) and total amount of axonally transported proteins (Heacock and Agranoff, 1982; Perry, Burmeister, and Grafstein, 1987; Perry, Burmeister, and Grafstein, 1990). In the fifth week postaxot-

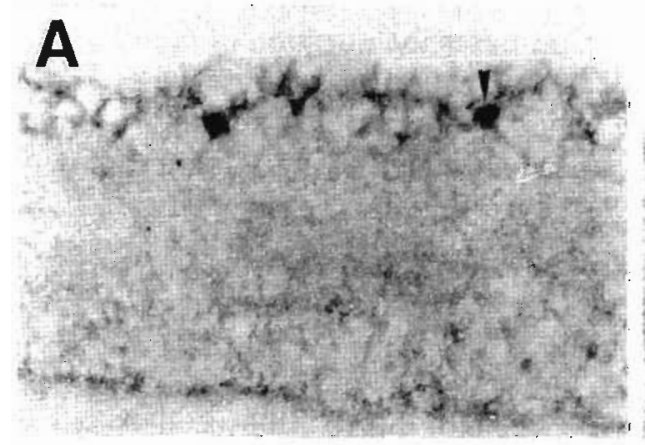

B

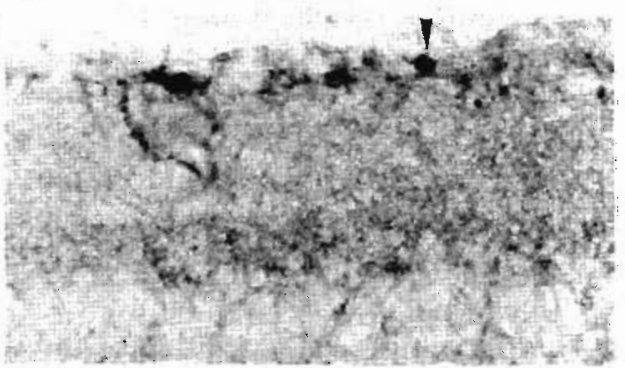

Figure 9 KROX-24-IR in rat RGCs after 5 days (A) and 8 days (B) following optic nerve crush. Arrowheads mark labeled nuclei in RGC layer. Magnification, $600 \times$. 
omy, the regenerating axons have extended over the whole of the optic tectum with development of synaptic effectiveness (Meyer, 1980; Schmidt et al., 1983; Stuermer and Easter, 1984; Stuermer, 1988 ). During this time, the number of JUN-positive RGCs had declined by around 30\%, and the amount of proteins of slow axonal transport was also reduced (Larrivee and Grafstein, 1989). JUNIR was still visible in some scattered cells after 100 days, when the metabolic and functional changes have been reverted to normal (Burmeister and Grafstein, 1985) apart from some defined events such as fine remodeling of synaptogenesis (Stuermer and Easter, 1984) and elevated expression of $N$-CAM protein (Bastmeyer et al., 1990).

The CREB transcription factor was present in apparently all RGCs and neurons of INL in untreated goldfish. Following ON lesion, the number of RGCs labeled by CREB and the intensity of labeling were reduced between 5 and 30 days. This decrease of CREB expression paralleled the period of maximal cell body response and maximal JUNIR. The constitutive expression and the decrease of CREB expression due to axotomy has also been observed in rat neurons (Gonzalez et al., 1989; Herdegen et al., 1992b). Following unilateral ON cut, JUN-IR remained absent and CREB-IR remained unchanged in RGCs of the intact eye, where the protein synthesis is not affected (McQuarrie and Grafstein, 1982).

\section{Transcription Factors in Axotomized Rat RGCs}

Specific anti-c-JUN (code 607/3) and anti-JUN D antibodies gave distinct and different nuclear signals in rat RGCs. JUN D-IR was visible in RGCs of untreated rats and in RGCs of the late postaxotomy period, as well as in nuclei of the inner nuclear layer, whereas c-JUN-IR was absent in RGCs of untreated rats and in the late postaxotomy period. The pattern of CREB-IR in the rat retina was similar to that of the goldfish retina. In both species, CREB was constitutively expressed in RGCs and INL. Following ON lesion, JUN proteins were faster expressed in rat RGCs compared to goldfish RGCs. This rapid onset could be related to rapid reactive glial responses that precede and possibly mediate the RGC responses to axotomy ( $\mathrm{Bähr}$ and Schlosshauer, 1989; Bähr, 1991; Carmignoto, Comelli, Candeo, Cavicchioli, Yan, Merighi, and Maffei, 1991). ON crush also induced KROX-24 in rat RGCs with a delayed onset compared to c-
JUN expression. Recently, a delayed expression of KROX-24 was also observed in axotomized neurons following transection of rat central nerve fiber tracts (Herdegen, Brecht, Bravo, and Zimmerman, 1992a). In contrast, peripheral nerve transection does not induce KROX-24 (Herdegen et al., 1992b). The maximal expression of JUN and KROX-24 proteins was seen after 5 days, followed by a rapid decline. Expression of JUN and KROX24 proteins preceded the changes in protein synthesis and RNA turnover in rat RGCs such as increase of GAP-43 (Doster, Lozano, Aguayo, and Willard, 1991), decrease of mRNA (Barron et al., 1985), and selective decrease of the proteins of the slow axonal transport (McKerracher, Vidal-Sanz, Essagian, and Aguayo, 1990; McKerracher and Hirscheimer, 1992). The temporal pattern of transient expression of JUN and KROX-24 proteins fairly corresponds to the abortion of initial sprouting response of injured ON axons after 5 days (Bähr et al., 1988; Bähr and Bunge, 1990; Bähr, 1991). The abortion of axonal sprouting is followed by death of RGCs starting after 1 week (Richardson, Issa, and Shemie, 1982; Barron et al., 1986; VillegasPerez et al., 1988). However, the strong decrease of c-JUN, JUN D, and KROX-24 expression is not merely the consequence of the RGC death because the CREB-IR in the RGC layer indicates the viability of many RGCs. Similar to goldfish, CREB-IR was also reduced in rat RGCs following $O N$ lesion. We have not investigated to what extent this decrease of CREB is an intrinsic reaction to axotomy and/or due to RGC death.

\section{Molecular Genetic Effects of Transcription Factor Expression}

Axotomy evokes a selective expression of JUN proteins whereas FOS proteins are not expressed (Sharp, Griffith, Gonzalez, and Sagar, 1989; Leah et al., 1991; Herdegen et al., 1992b). This observation raises the question of how JUN proteins exert their function in the absence of FOS proteins because FOS proteins strongly increase the DNA binding activities of JUN proteins (Hirai et al., 1989; Zerial, Toschi, Ryseck, Schuermann, Müller, and Bravo, 1989; Ryseck and Bravo, 1991). c-JUN can form transcriptional complexes not only with JUN and FOS proteins but also with CREB-related proteins such as CRE-BP1 (Benbrook and Jones, 1990; Macgregor et al., 1990) and with helix-loop-helix proteins such as MyoD (Bengal, Ransone, Scharfmann, Dwarki, Tapscott, 
Weintraub, and Verma, 1992). JUN D can form heterodimers with JUN proteins (Hirai et al., 1989; Ryseck and Bravo, 1991) and CREB forms dimers with members of the ATF/CREB family (reviewed by Ziff, 1990). c-JUN, JUN D, and CREB bind to AP-1 and/or CRE consensus sequences of both regulator and effector genes (Macgregor et al., 1990; Ryseck and Bravo, 1991). Thus, the expression of c-JUN, JUN D, and CREB enables axotomized neurons to perform variable transcriptional operations. The KROX-24 transcription factor belongs to the family of "zinc finger" proteins (Milbrandt, 1987; Chavrier, Zerial, Lemaire, Almendral, Bravo, and Charnay, 1988; Christy, Lau, and Nathans, 1988; Lemaire, Relevant, Bravo, and Charnay, 1988; Sukhatme, $\mathrm{Cao}$, Chang, Tsai-Morris, Stamenkovich, Ferreira, Cohen, Edwards, Shows, Curran, LeBeau, and Adamson, 1988). In vitro and in vivo experiments have demonstrated that expression of KROX-24 is coregulated with c-FOS following transynaptic stimulation (Sukhatme et al., 1988; Herdegen et al., 1991a; Gass et al., 1992). The expression of KROX-24 in the absence of FOS also indicates a selective activation of potent pathways for gene expression in axotomized neurons that differ from those activated by transynaptic stimulation.

Which are the possible target genes and cellular processes controlled by JUN and KROX-24 proteins in axotomized neurons? In the goldfish, appearance of JUN-IR precedes and outlasts the increase in de novo synthesis evoked by $\mathrm{ON}$ lesions (Murray and Grafstein, 1969). However, the relation to changes of total protein synthesis has to be interpreted with precautions because changes in protein synthesis comprise both induction and suppression. The pool of proteins induced by axotomy of goldfish RGCs includes numerous substances such as $\alpha$ - and $\beta$-tubulin (Giulian, Des Ruisseaux, and Cowburn, 1980; Neumann, Scherson, Ginzburg, Littauer, and Schwartz, 1983), actin (Quitschke and Schechter, 1983), microtubuleassociated proteins (Neumann et al., 1983), growth-associated cell surface proteins such as $\mathrm{N}$ CAM (Coughlin and Elam, 1989; Bastmeyer et al., 1990; Vielmetter, Lottspeich, and Stuermer, 1991; Paschke, Lottspeich, and Stuermer, 1992), and growth-associate proteins such as GAP-43 (Doster et al., 1991). Whereas cytoskeleton- and growthassoeiated proteins return to control values between 50 and 80 days, synthesis of $N$-CAM protein persists on elevated levels up to 250 days. Thus, the time course of JUN-IR parallels that of most effec- tor proteins and can be generally related to the changes of protein synthesis. As for the absence of c-JUN after 200 days, the antibody used may not detect possibly existing low levels of JUN protein(s). For the evaluation of the target genes controlled by JUN protein(s), it is of particular interest that $\mathrm{ON}$ lesion increases all those axonally transported proteins that are already present in untreated goldfish and that the increase in protein synthesis is a general event rather than a specific reaction (Grafstein, Burmeister, McGuiness, Perry, and Sparrow, 1987; Perry et al., 1987; Fawcett, 1991). This observation might attribute to JUN protein (s) a role of a general enhancer of gene transcription. Further, it remains to be elucidated whether the decrease of CREB protein could be responsible for the increase of expression of JUN protein (s) or vice versa.

In contrast to goldfish, sprouting rat RGCs do not pass through the extracellular environment formed by oligodendrocyte and CNS myelin-associated proteins (Villegas-Perez et al., 1988; Bähr and Bunge, 1990; Bähr, 1991). Following intraorbital crush, RGCs show a transient axonal sprouting that is blocked by extraorbital nonpermissive substrates. In goldfish and rat RGCs, JUN proteins are expressed due to axotomy irrespective of the fate of axonal sprouting. These findings correspond to the expression of regeneration-associated proteins, which is equal during the initial cell body response of regenerating and nonregenerating neurons (Tetzlaff et al., 1991).

\section{CONCLUSIONS}

The extraneuronal matrix of neurons plays a decisive role for the successful sprouting of lesioned neurons (David and Aguayo, 1981; Vidal-Sanz, Bray, Villegas-Perez, Thanos, and Aguayo, 1989; Schnell and Schwab, 1990; Bastmeyer, Beckmann, Schwab, and Stuermer, 1991; David, Bouchard, Tsatas, and Giftochristos, 1991). However, neurons also differ in their intrinsic potencies for sprouting (reviewed by Fawcett, 1992). The expression of JUN proteins seems to be a general principle following axotomy whereas the persistence of JUN expression is differentially regulated in lesioned neurons (Herdegen et al., 1991b, 1992a,b, 1993). We suggest that this differential presence reflects the short- or long-lasting intrinsic potency for axonal sprouting.

Together with previously reported data, our present results provide evidence that the expres- 
sion of C-JUN, JUN D, and KROX-24 and the decrease of CREB protein are involved in the signal-transcription coupling between nerve lesion and the regeneration-associated protein synthesis. The presence of JUN and KROX transcription factors may underly the molecular genetic readiness for regeneration and the regenerative potency. However, the question remains to be solved whether the increase of JUN and KROX-24 proteins are prerequisites for axonal sprouting or a coincident event with yet unknown functions.

The visualisation of transcription factor expression presents a novel approach to provide insight into the link between expression of individual genes and the control of axon growth (Herdegen et al., 1993).

This work was supported by the Deutsche Forschungsgemeinschaft, Forschergruppe $\mathrm{Zi} \mathrm{110/22.} \mathrm{The} \mathrm{authors}$ thank Anja Buhl and Ursula Topel for excellent technical assistance.

\section{REFERENCES}

Allcutt, D., BerRy, M., and Sievers, J. (1984). A quantitative comparison of the reactions of retinal ganglion cells to optic nerve crush in neonatal and adult mice. Dev. Brain Res. 16:219-230.

Almendral, J. M., SOMMER, D., MaCDonaldBravo, H., BurckHard, J., Perera, J., and Bravo, R. (1988). Complexity of the early genetic response to growth factors in mouse fibroblasts. Mol. Cell. Biol. 8:2140-2148.

BÄHR, M. (1991). Adult rat retinal glia in vitro: Effects of in vivo cush-activation on glia proliferation and permissiveness for regenerating retinal ganglion cell axons. Exp. Neurol. 111:64-73.

BÄHR, M. and BUNGE, R. P. (1990). Growth of adult rat retinal ganglion cell neurites on astrocytes. Glia 3:293-300.

BÄHR, M. and SCHLOSSHAUER, B. (1989). JONES ganglioside expression on retinal glia increases after axotomy. J. Neurocytol. 18:553-565.

BÄHR, M., VANSELOW, J., and Thanos, S. (1988). In vitro regeneration of adult rat ganglion cell axons from retinal explants. Exp. Brain Res. 73:207-216.

Barron, K. D., Dentinger, M. P., Krohel, G., EasTON, S. K., and MANKES, R. (1986). Qualitative and quantitative ultrastructural observations on retinal ganglion cell layer of rat after intraorbital optic nerve crush. J. Neurocytol. 15:345-362.

BarRon, K. D., McGuiness, C. M., Misantone, L. J., Zanakis, M. F., Grafstein, B., and Murray, M. (1985). RNA content of normal and axotomized reti- nal ganglion cells of rat and goldfish. J. Comp. Neurol. 236:265-273.

Bartel, D. P., ShenG, M., LaU, L. F., and Greenberg, M. E. (1989). Growth factors and membrane depolarization activate distinct programs of early response gene expression: Dissociation of fos and jun induction. Genes Dev. 3:304-313.

Bastmeyer, M., BeckmanN, M., SChwab, M., and STUERMER, C. (1991). Growth of regenerating gold fish axons is inhibited by rat oligodendrocytes and CNS myelin but not by goldfish optic nerve tract oligodendrocyte like cells and fish CNS myelin. $J$. Neurosci. 11:626-640.

BASTMEYeR, M., Schlosshauer, B., and StUermer, C. A. O. (1990). The spatiotemporal distribution of $\mathrm{N}$-CAM in the retinotectal pathway of adult goldfish detected by the monoclonal antibody D3. Development 108:299-311.

BenBrook, D. M. and Jones, N. C. (1990). Heterodimer formation between CREB and JUN proteins. Oncogene 5:295-302.

Bengal, E., Ransone, L., Scharfmann, R., Dwarki, V. J., TApscott, S. J., Weintraub, H., and Verma, 1. (1992). Functional anatgonism between c-Jun and MyoD proteins: A direct physical association. Cell 68:507-519.

Boshart, M., WeIH, F., Nichols, M., and SChÜtz, G. (1991). The tissue-specific extinguisher locus TSE1 encodes a regulatory subunit of cAMP-dependent protein kinase. Cell 66:849-859.

BRAvo, R. (1990). Growth factor inducible genes in fibroblasts. In: Growth Factors, Differentiation Factors and Cytokines. A. Herschman, Ed. Springer-Verlag, Berlin, pp. 324-343.

Burmeister, D. W. and Grafstein, B. (1985). Removal of optic tectum prolongs the cell body reaction to axotomy in goldfish retinal ganglion cells. Brain Res. 327:45-51.

Carmignoto, G., Comelli, M. C., Candeo, P., CavicChioli, L., Yan, Q., Merighi, A., and Maffei, L. (1991). Expression of NGF receptor and NGF receptor mRNA in the developing and adult rat retina. Exp. Neurol. 111:302-3।1.

Chavrier, P., Zerial, M., Lemaire, P., Almendral, J., Bravo, R., and Charnay, P. (1988). A gene encoding a protein with zinc fingers is activated during G0/Gl transition in cultured cells. EMBO J. 7:29-35.

Christy, B. A., LaU, L. F., and Nathans, D. (1988). A gene activated in mouse $3 \mathrm{~T} 3$ cells by serum growth factors encodes a protein with "zinc finger" sequences. Proc. Natl. Acad. Sci. USA 85:7857-7861.

Coughlin, C. and Elam, J. S. (1989). Enhanced axonal transport of glycosaminoglycans in regenerating goldfish optic nerve. Brain Res. 493:326-330.

DAvid, S. and AGUAYO, A. (1981). Axonal elongation into peripheral nervous system "bridges" after central nervous system injury in adult rats. Science 214:931 933. 
David, S., Bouchard, C., Tsatas, O, and GifTOCHRISTOS, N. (1991). Macrophages can modify the non-permissive nature of the adult mammalian central nervous system. Neuron 5:463-469.

Dokas, L. A., Kohsaka, S., Burrell, H. R., and AGRANOFF, B. W. (1981). Uridine metabolism in the goldfish retina during optic nerve regeneration: Whole retina studies. J. Neurochem. 36:1 160-1165.

Doster, S. K., Lozano, A. M., Aguayo, A. J., and WILLARD, M. B. (1991). Expression of the growth-associated protein GAP-43 in adult rat retinal ganglion cells following axon injury. Neuron 6:635-647.

FAwCETT, J. W. (1992). Intrinsic neuronal determinants of regeneration. Trends Neurosci. 15:5-8.

Gass, P., Herdegen, T., Kiessling, M., and Bravo, R. (1992). Induction of immediate early gene encoded proteins in the rat hippocampus after bicuculline-induced seizures: Differential expression of KROX-24, FOS and JUN proteins. Neuroscience 48:314-323.

Giullan, D., Des Ruisseaux, H., and Cowburn, D. (1980). Biosynthesis and intra-axonal transport of proteins during neuronal regeneration. J. Biol. Chem. 255:6494-6501.

Gonzalez, G. A., Yamamoto, K. Y., Fischer, W. H., KarR, D., MENZEL, P., BigGS, W. III, VALE, W. W., and MONTMINY, M. R. (1989). A cluster of phosphorylation sites on the cyclic AMP-regulated nuclear factor CREB predicted by its sequence. Nature 337:749752.

Goodman, R. H. (1990). Regulation of neuropeptide gene expression. Annu. Rey. Neurosci. 13:111-127."

GrafsteIN, B. (1986). The retina as a regenerating organ. In: The Retina. A Model for Cell Biology Studies, Part II. R. Adler and D. Farber, Eds. Academic Press, New York, pp. 275-335.

Grafstein, B., Burmeister, D. W., McGuiness, C. M., Perry, G. W., and Sparrow, J. R. (1987). Role of fast axonal transport in regeneration of goldfish optic axons. Prog. Brain Res. 71:113-120.

Heacock, A. and Agranoff, B. W. (1982). Protein synthesis and transport in the regenerating goldfish visual system. Neurochem. Res. 7:771-788.

HeNGerer, B., LindHOlM, D., HeumanN, R., Rüther, U., WAGNer, E. F., and Thoenen, $H$. (1990). Lesion-induced increase in nerve growth factor mRNA is mediated by c-fos. Proc. Natl. Acad. Sci. USA 87:3899-3903.

Herdegen, T., Brecht, S., Bravo, R., and ZimmerMANN, M. (1992a). Increase in expression of JUN and KROX proteins and of nitric oxide synthase immunoreactivity following transection of the medial forebrain bundle in the rat CNS. Soc. Neurosci. Abstr. 18: 1463.

Herdegen, T., Fiallos-Estrada, C. E., Bravo, R., and ZimmermanN, M. (1993). Colocalisation and covariation of the nuclear C-JUN protein with galanin in primary afferent neurons and with CGRP in spinal motoneurons following transection of rat sciatic nerve. Mol. Brain Res. 17:147-154.
Herdegen, T., Fiallos-Estrada, C. E., Schmid, W., Bravo, R., and ZimMERManN, M. (1992b). The transcription factors c-JUN, JUN D and CREB, but not FOS and KROX-24, are differentially regulated in neurons following axotomy of rat sciatic nerve. $\mathrm{Mol}$. Brain Res. 14:155-165.

Herdegen, T., Kovary, K., LeaH, J., and Bravo, R. (1991a). Specific temporal and spatial distribution of JUN, FOS and KROX-24 proteins in spinal neurons following noxious transynaptic stimulation. J. Comp. Neurol. 313:178-191.

Herdegen, T., Kummer, W., Fiallos, C. E., Leah, J., and Bravo, R. (1991b). Expression of c-JUN, JUN B and JUN D in the rat nervous system following transection of vagus nerve and cervical sympathetic trunk. Neuroscience 45:413-422.

Herdegen, T., Leah, J., Manisali, A., Bravo, R., and ZIMMERMANN, M. (1991c). c-JUN-like immunoreactivity in the CNS of the adult rat: Basal and transynaptically induced expression of an immediate-early gene. Neuroscience 41:643-654.

HiRAI, S. I., R ySECK, R. P., Mechta, F., Bravo, R., and YANIV, M. (1989). Characterisation of jun D: A new member of the jun protooncogene family. EMBO J. 8:1433-1439.

JENKINS, R. and HunT, S. P. (1991). Long-term increase in the levels of c-jun mRNA and JUN proteinlike immunoreactivity in motor and sensory neurons following ax on damage. Neurosci. Lell. 129:107-1 10.

JoHNS, P. R. and EASTER, S. S. (1977). Growth of the adult goldfish eye. II: Increase in retinal cell number. J. Comp. Neurol. 176:331-342.

KEEFE, J. R. (1973). Analysis of urodelian retinal regeneration: IV. Studies of the cellular source of retinal regeneration in Friturus cristatus carrifex using ${ }^{3} \mathrm{H}$ thymidine. J. Exp. Zool. 184:239-258.

KOVARY, K. and BRAVO, R. (1991). Expression of different JUN and FOS proteins during the G0 to G1 transition in mouse fibroblasts: In vitro and in vivo associations. Mol. Cell. Biol. 11:2451-2459.

KUSCHEL, C. and STUERMER, C. A. O. (1988). Axotomy of retina axons causes ganglion cell death in young larvae of zebra fish. Soc. Neurosci. Abstr. 14:267.18.

LAMPH, W. W., DWARKI, V. J., OFIR, R., MONTMINY, M., and VerMA, I. M. (1990). Negative and positive regulation by transcription factor CAMP response element-binding protein is modulated by phosphorylation. PNAS 87:4320-4324.

LARRIVEE, D. C. and GRAFSTEIN, B. (1989). Relationship between phosphorylation and synthesis of goldfish optic nerve proteins during regeneration. J. Neurosci. 9:574-581.

Leah, J., Herdegen, T., Kovary, K., and Bravo, R. (1991). Selective expression of JUN proteins following peripheral axotomy and axonal transport block in the rat: Evidence for a role in the regeneration process. Brain Res. 566:198-207.

Lemaire, P., Relevant, O., Bravo, R., and Charnay, P. (1988). Two mouse genes encoding potential tran- 
scription factors with identical DNA-binding domains are activated by growth factors in cultured cells. Proc. Natl. Acad. Sci. USA 85:4691-4695.

LIEBERMANN, A. R. (1974). Some factors affecting retrograde neuronal responses to axonal lesions. In: Essays on the Nervous System. R. Bellairs and E. G. Gray, Eds. Clarendon Press, Oxford, UK, pp. 7 l-105.

LowENGER, E. and LeVINE, R. L. (1988). Studies of the early stages of optic axon regeneration in the goldfish. J. Comp. Neurol. 271:319-330.

MacGregor, P. F., Abate, C., and Curran, T. (1990). Direct cloning of leucine zipper proteins: Jun binds cooperating to the CRE with CRE-BP1. Oncogene 5:451-458.

MCKerRacher, L. and HirSCheimer, A. (1992). Slow transport of the cytoskeleton after axonal injury. $J$. Neurobiol. 23:568-578.

McKerracher, L., Vidal-Sanz, M., Essagian, C., and AGUAYo, A. J. (1990). Selective impairment of slow axonal transport after optic nerve injury in adult rats. J. Neurosci. 10:2834-2841.

MCQUARrie, I. and GrafsteIn, B. (1982a). Protein synthesis and fast axonal transport in regenerating goldfish retinal ganglion cells. Brain Res. 235:213223.

MCQuarrie, 1. and Grafstein, B. (1982b). Protein synthesis and axonal transport in goldfish retinal ganglion cells during regeneration accelerated by a conditioning lesion. Brain Res. 251:25-37.

MEYER, R. L. (1980). Mapping the normal and regenerating retinotectal projection of goldfish with autoradiographic methods. J. Comp. Neurol. 189:273-289.

MilbRandT, J. (1987). A nerve growth factor-induced gene encodes a possible transcriptional regulatory factor. Science 238:797-799.

Misantone, L. J., Gershbaum, M., and Murray, M. (1984). Viability of retinal ganglion cells after optic nerve crush in adult rats. $J$. Neurocytol. 13:449-465.

Murray, M. (1973). ${ }^{3} \mathrm{H}$-Uridine incorporation by regenerating retinal ganglion cells of goldfish. Exp. Neurol. 39:489-497.

Murray, M. and Grafstein, B. (1969). Changes in the morphology and amino acid incorporation of regeneration goldfish optic neurons. Exp. Neurol. 23:544-560.

Naranjo, J. R., Mellström, B., Achaval, and SasSONE-CORSI (1991). Molecular pathways of pain: Fos/Jun-mediated activation of a noncanonical AP-1 site in the prodynorphin gene. Neuron 6:607-617.

NeumanN, D., Scherson, T., GinzburG, J., LiTTAUER, U. Z., and SCHWARTZ, M. (1983). Regulation of mRNA-levels of microtube proteins during nerve regeneration. FEBS Lett. 162:270-276.

PAsChKe, K. A., LotTSPeich, F., and Stuermer, C. A. O. (1992). Neurolin, a cell surface glycoprotein on growing retinal axons in the goldfish optic nerve during degeneration and regeneration following nerve crush. J. Cell Biol. 117:863-875.

Perry, G. W., Burmeister, D. W., and Grafstein, B. (1987). Fast axonally transported proteins in regenerating goldfish optic axons. J. Neurosci. 7:792-806.
Perry, G. W., Burmeister, D. W., and Grafstein, B. (1990). Effect of target removal on goldfish optic nerve regeneration: Analysis of fast axonally transported proteins. J. Neurosci. 10:3439-3448.

QUITSCHKE, W. and SCHECHTER, N. (1983). In vitro protein synthesis in the goldfish retinotectal pathway during regeneration: Evidence for specific axonal proteins of retinal origin in the optic nerve. $J$. Neurochem. 41:1137-1142.

Richardson, P. M., ISSA, V. M. K., and Shemie, S. (1982). Regeneration and retrograde degeneration of axons in the rat optic nerve. $J$. Neurocytol. 11:949966.

RYSECK, R. and BRAVO, R. (1991). c-JUN, JUN B, and JUN D differ in their binding affinities to AP-1 and CRE consensus sequences: Effect of FOS propteins. Oncogene 6:533-542.

RysecK, P., Hirai, D., Yaniv, M., and Bravo, R. (1988). Transcriptional activation of c-jun during the G0/Gl transition in mouse fibroblasts. Nature 334:535-537.

SCHMidT, J. T., EDwards, D. L., and STUERMER, C. A. O. (1983). The re-establishment of synaptic transmission by regenerating optic axons in goldfish: Time course and effects of blocking activity by intraocular injection of tetrodotoxin. Brain Res. 269:15-27.

SCHNELl, L. and Schwab, M. E. (1990). Axonal regeneration in the rat spinal cord produced by antibody against myelin-associated neurite growth inhibitors. Nature 343:269-272.

SharP, F. R., Griffith, J., GonZalez, M. F., and SAGAR, S. M. (1989). Trigeminal nerve section induces Fos-like immunoreactivity (FLI) in brainstem and decreases FLI in sensory cortex. Mol. Brain Res. 6:217220.

ShenG, M., McFadden, G., and GreenberG, M. E. (1990). Membrane depolarization and calcium induce $c$-fos transcription via phosphorylation of transcription factor CREB. Neuron 4:57I-582.

SKENE, J. H. P. (1989). Axonal growth-associated proteins. Annu. Rev. Neurosci. 12:127-156.

SONNENBERG, J. L., MACGREGor-LeON, P. F., Curran, T., and Morgan, J. I. (1989a). Dynamic alterations occur in the levels and compositions of transcription factor AP- 1 complexes after seizure. Neuron 3:359-365.

SONNEnberG, J. L., Rauscher, F. J. III, Morgan, J. I., and CURRAN, T. (1989b). Regulation of proenkephalin by fos and jun. Science 246:1622-1625.

STUERMER, C. A. O. (1988). Trajectories of regenerating retinal axons in the goldfish tectum: I. A comparison of normal and regenerated axons at late regeneration stages. J. Comp. Neurol. 267:55-68.

STUERMER, C. A. O., BASTMEYER, M., BÄHR, M., STROBEL, G, and PASCHKE, K. (1992). Trying to understand axonal regeneration in the CNS of fish. J. Neurobiol. 23:537-550.

Stuermer, C. A. O. and Easter, S. S. (1984). A com- 
parison of the normal and regenerated retinotectal pathways of goldfish. J. Comp. Neurol. 223:57-76.

Sukhatme, V. P., Cao, X. M., Chang, L. C., TsaiMorris, C. H., StamenKovich, D., Ferreira, P. C. P., Cohen, D. R., Edwards, S. A., Shows, T. B., Curran, T., Lebeau, M. M., and Adamson, E. D. (1988). A zinc finger-encoding gene coregulated with c-fos during growth and differentiation, and after cellular depolarisation. Cell 53:37-43.

Tetzlaff, W., Alexander, S. W., Miller, F. D., and BISBY, M. A. (1991). Response of facial and rubrospinal neurons to axotomy: Changes in mRNA expression for cytoskeletal proteins and GAP-43. J. Neurosci. 11:2528-2544.

VIDAl-Sanz, M., Bray, G. M., Villegas-Perez, M. P., Thanos, S., and Aguayo, A. (1989). Axonal regeneration and synapse formation in the superior colliculus by retinal ganglion cells in the adult rat. $J$. Neurosci. 7:2894-2909.

VIELMETTER, J., LOTTSPEICH, F., and STUERMER,
C. A. O. (1991). The monoclonal antibody E 587 recognizes growing (new and regenerating) retinal axons in the goldfish retinotectal pathway. J. Neurosci. 11:3581-3593.

Villegas-Perez, M. P., Vidal-SAnZ, M., Bray, G. M., and AGUAYO, A. J. (1988). Influences of peripheral nerve grafts on the survival and regrowth of axotomized retinal ganglion cells in adult rats. J. Neurosci. 8:265-280.

WhitNall, M. H. and Grafstein, B. (1983). Changes in perikaryal organelles during axonal regeneration in goldfish retinal ganglion cells: An analysis of protein synthesis and routing. Brain Res. 272:49-56.

Zerial, M., TosChI, L., Ryseck, R. P., SchuermanN, M., Müller, R., and BRAvo, R. (1989). The product of a novel growth factor activated gene, fos' B, interacts with JUN proteins enhancing their DNA binding activity. EMBO J. 8:805-813.

ZIFF, E. (1990). Transcription factors: A new family gathers at the cAMP response site. $T I G$ 6:69-72. 